震災前の木造密集市街地の実態と被災による市街地建物・ 住宅被害の構造に関する研究

\title{
THE STUDY ABOUT THE ACTUAL CONDITION OF WOODEN CLUSTERED HOUSES AREAS BEFORE THE EARTHQUAKE, AND THE MECHANISM OF DAMAGES IN THESE AREAS
}

\author{
安藤元夫*, 幸田 稔**, 小島 孜***, 曾根秀一**** \\ Motoo ANDOU, Minoru KOUDA, Tsutomu KOJIMA \\ and Syumichi SONE
}

\begin{abstract}
The noticeable point of The Hanshin-Awaji Earthquake is enormous damages in inner city ,especially in wooden clustered houses area.

In order to generalize the damages of clustered houses, we have made comprehensive surveys in 4 areas where had different kind of earthquake shock.( 3 areas had a shock with seismic intensity of 7,the other had with 6)

The purpose of this study is making following points clear.

1. The factor of damages in the wooden clustered houses areas.(The relationship of structure,arrangement,construction time to the degree of damages)
\end{abstract}

2. What the wooden clustered houses areas used to be before the earthquake.

Keyword : Hanshin-awaji Earthquake, Wooden clustered houses areas, the damages of city, the damages clustered houses 阪神・淡路大震災, 木造密集市街地, 市街地被害, 住宅被害

\section{1. 研究の目的}

阪神・淡路大震災の特徽は，インナーシティーの被害，とりわけ 木造密集市街地での被害が大きかったことである。木造密集市街地 に立地する住宅は, 老朽戸建住宅, 長屋住宅, 文化住宅・木造ア パート拜が多く，震度 7 の放震地域では，これらの住宅の多く が全・半塤した。

今回の大震災では木造密集市街地の被害，住宅の被害を明らかに することが求められるが，その点が十分には解明されていない。建 物被災度については，震災直後に都市計画学会，建築学会が共同し て明石市から尼崎市まで，一部大阪市までを棟単位で調查した。そ れを都市住宅学会が戸数ベースに補強調查したものが最も詳しい データである。住宅被害研究についての成果には，都市住宅学会の 研究1)，村上らの研究2)などがあるが，前者は被害戸数を全般的に把 握したものであり，後者は特定の地区での被害の建物要因分析を 行っている。それ以外の研究では, 木造住宅事例をとりだし被害・ 破壊の詳細分析を行っているものが多い3)。震災 3 年を経て岸本の 被災住宅戸数の再考4) や三宅の13大都市の住宅被害予澌の研究5) と いった研究も行われだしている。しかしながらいくつかの地区でか なりの数の住戸を対象にして市街地被害，住宅被害の要因を具体的 に分析し，ある地区の特殊解でなく，一般化，客钼化を図ろうとす
る研究は多くない。本研究ではそのことを意識しているะ2)。 本研究の目的は, 木造密集市街地を対象に，以下の点を明らかに することである。第 1 には，木造密集市街地の被害，とりわけ住宅 被害の要因分析を行うことである。地震被害は，地震動（震度，摇 れ）を基本に建物条件，地盤，市街地の状況等が関係する。本論文 では，建物・住宅条件，とりわけ構造，住宅形式，建築特期と被害 の関係について地震動の異なる 4 地区（震度 7 の 3 地区と震度 6 の 1 地区）を対象に比較考察することで被害要因の関係を明らかにし ようとする。第 2 には，こうした分析の前提ともなる地震前の木造 密集市街地の実䘒を明らかにすることである。

2. 調查対象地区の選定と調査の種類, 方法

2.1 対象地区の選定と特徽

木造密集市街地での被害を一般化するため, 以下の 4 点を指標と して調查対象を選定し比較分析を行う。選定に当たっての指標は， (1)被害の大きさ, (2)専用的住宅地区か, 工業・商業等との混在地区 かといった市街地の性格, (3)基盤整備の有無, (4)震災後土地区画整 理事業や市街地再開発事業等の都市計画事業が行われている地区か そうでない白地区域が徃3)，という4点である。

(1)芦屋市精道小学校区の北部分（以下，芦屋地区と略称）-- - 住

\footnotetext{
* 近畿大学理工学部建築学科 教授・土博

** 近畿大学理工筙部建築学科 助手

*** 近畿大学理工学部建築学科 教授

**** 近畿大学理工学部建築学科 講師
}

Prof., Dept. of Architecture, Faculty of Science and Engineering, Kinki Univ., Dr. Eng.

Research Assoc., Dept. of Architecture, Faculty of Science and Engineering, Kinki Univ.

Prof., Dept. of Architecture, Faculty of Science and Engineering, Kinki Univ. Lecturer, Dept. of Architecture, Faculty of Science and Engineering, Kinki Univ. 


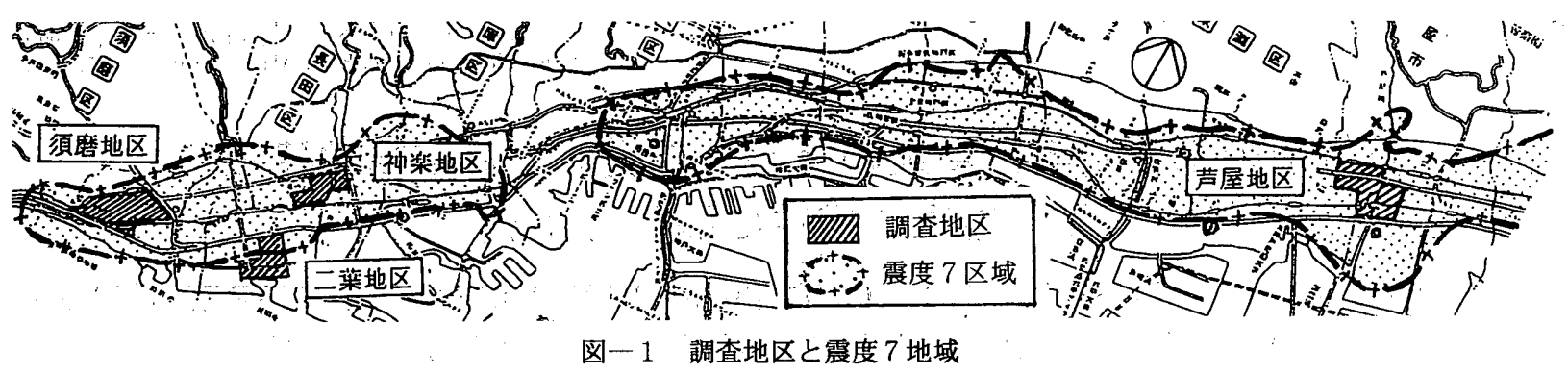

宅密集地区で北部分は基盤未整備である，西部地区，中央地区とい う2つの復興土地区画整理事業が行われている。地区の形成は, 明 治後半に開業した阪神電鉄駅周辺開発と芦屋川扇状地の的宅建設に 始まる。大正期の精道村耕地整理事業は市街化の進行を速める契機 となったが, 地区の多くは戦後すくの混乱期に市街化している。

(2)神戸市長田区神楽小学校区（神楽地区と略称）- - - ケミカル シューズ産業で代表される住工混在地区，100 $\mathrm{m}$ 街区単位では基蟞 整備されているが，街区内部は幅員 $3 \mathrm{~m}$ 程度の細街路である。対象 地区の西半分と東端部分が復興区画整理地区に指定されている。

(3)神户市長田区二葉小学校区（二葉地区之略称）-- - 連担商店街 からなる住商混在地区で, $100 \mathrm{~m}$ 街区単位では基整整備されている。 地区北東部は火災て焼失し,20haの大規模な再開発事業地区に指定 された。これら長田区神楽地区, 二莱地区は大正期の神戸西部耕地 整理事業によって市街化が進んだ。農業用水用に当初は溜池が残さ れたが，予想を上回る市街化の進行でその多くが埋め立てられた。

(4)神戸市須磨区西須磨小学校区の東部分（須磨地区と略称）-- 木造密集住宅地区で地区南東部の一部を除くと，基盤が未整備であ る。地震後, 地区の西部に 3 本の幹線道路計画が事業計画決定され た。第一次世界大戦後から急速に市街化が進み, 昭和初期まてに多 くの民間借家が供給された。須磨地区は扇状地で㖽斜地が多からた ことと、既に市街化が進んでいたことから耕地整理は行われなかっ た。その結果, 細街路だけの無秩序な開発を許す結果となった。

調查対象地区と震度 7 地域の閏係を示したのが闵一 1 で、地区の 概要を示したのが表一1である。

\section{2 調查の種類}

本論文で，使用している調查の種類と方法は次の通りである。

\section{(1) 建物被害媩査}

建物被害調查については，日本都市計画学会，日本建築学会が震 災直後に合同で行ったデータを使っている。長屋等の集合住宅の被 害については棟単位での戸数を把握するため、震災 1 年後の1996 年 3 月に独自に覞察・聴き取り䚴查を行った。

（2）被害分析のための雲災以前の建物デー夕解查

震災以前の 4 地区の旗查対象建物は，8,223棟で，そのうち住宅 は6,937棟，13,792戸である。

(1)建物用途，住宅形式-ー-住宅地図を基碄資料として現地钼察調

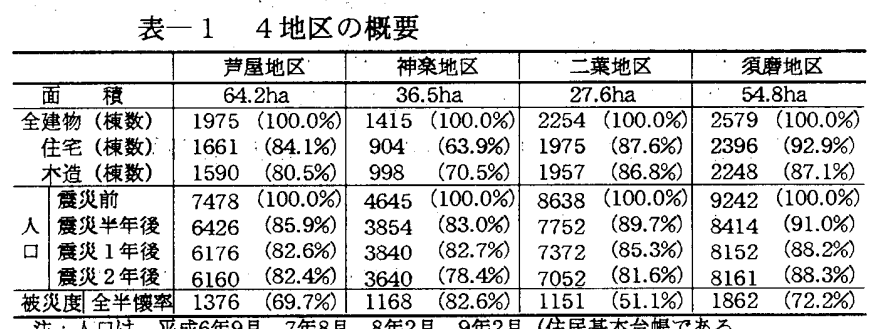

注：人口は、平成6年9月、7年8月、8年2月、9年2月（住民基本台根である。
查を行った。建物用途の内, 併用・併存住宅汭)については, 更地に なったものも含めてヒヤリング媩查で把提した。また，住宅形式に ついても更地等で把握の困難なものはヒヤリングを行った。

(2)構造; 階数-ー-ー建っているものは目視調查, 更地になったもの はヒアリング調查で把握した。

これらの建物用途, 住宅形式, 構造, 階数把握の調查時期は, 前 述した集合住宅の被害戸数調查と同様1996年3月である。

(3)建策時期- - - 建桑時期 (老朽度) は，建物被害要因を明らかに するための最も重要な指標の 1 つである。私たちは，10余年間程度 每の間隔（時期区分）で建箱年度が把晊できないかと考え，昭和 $23 ， 36 ， 47 ， 60$ 年および被災後という5 時点について国土地理院 が撮影した 4 地区の航空写真を購入し，各時点ごとに建物 1 棟つう を照合することによって建築時期を把挃する方法をとっだ5)。具体 的には，例えば昭和 47 年の写真で田㚼等に新たに住宅が立地してお れば，36年〜 47 年の建築時期であり，また昭和 36 年と 47 年の写真 で建物が異なっておれば36 年〜 47 年に建替えられたと判断した。 辣查作業時期は1995年11〜12月である。

\section{（3）本研究の分析の方法}

本論文では，木造密集市街地建物および主要素である住宅の実熊 と被害を分析する。木造密集市街地の実憄と被害を把握する方法は 容易ではない。ここでは，非住宅を含む木造市街地の全建物を専用 住宅，伊用:并存住宅，非住宅の別でとらえるという方法をとっ た。また論文の中心となる住宅被害の分析については，住宅形式 （戸建，長屋，文化・梏アパート，マンション，公営·公団·社 宅・寮等) を基本としている。図一 2 が本研究の分析の方法であ る。市街地建物は棟単位で, 住宅は棟, 戸数単位（戸数を主に）で とらえ，それぞれ建物用途, 楧造, 階数, 建築時期等との被害要因 分析を行う螘。

\section{3． 地震前の木造密集市街地の状况}

震災後の市街地建物・住宅被害や建物復旧状況といった時系列変 化をみるためにも震災前の建物や市街地の状況を把握することが重 要となる。また，より基碦的な問題として今回大きな被害を受け た木造密集市街地とは，どのような市街地だったのかを知る必要が ある。そこて，震災前の市街地の状況を表わす指標として，(1建物 用途，(2建物構造，(3)階数，(4)建努時期をとり，各々，専用住宅，

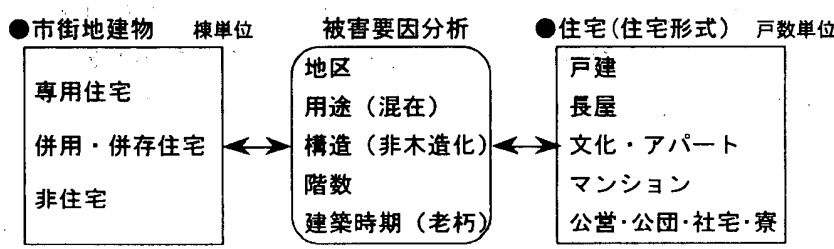

図一 2 本研究の分析方法 
併用・垪存住宅と非住宅の別が分かるように集計した。これにより 木造密集市街地の性格, すなわち住宅専用なのか（混在率），木造 特化なのか（木造率，または非木造率），低層なのか（階数），老 朽度はどれくららなのか（建物建築年代），といった点を把暒しょ うとした。そのうえで, 木造密集市街地の中心になる住宅をとりだ して住宅形式別に戸数，棟数をみている。

\section{1 建物の状況}

\section{1 .1 建物用途}

まず専用住宅，垪用・垪存住宅と非住宅の関係でみる。専用住宅 $69 \%$, 垪用・併存住宅 $15 \%$, 非住宅 $16 \%$ で非住宅が少ない。また 専用住宅以外の用途では店舗垪用 $5 \%$, 店赭尃用 $6 \%$ と店舗が多 い。

地区別にみると，須磨地区が専用住宅 $80 \%$ と最も住宅地的な性格 がつよく, 次いで芦屋, 二莱地区である。こうした専用住宅中心の 3 地区に対して, 神楽地区は住工混在地区である。専用住宅 (45\%) は少なく，併用・併存住宅（19\%）や非住宅（36\%）が多いこと が特徽である（表一2）。

\section{1 .2 建物構造 - 階数}

\section{(1) 建物構造}

全建物でみると，木造が83\%と大半を占める。とくに，専用住宅 （91\%）ではほぼすべてが木造である。并用・併存住宅では木造率 が71\%まで, 非住宅では5 6 \%まで下がる。それにかわって, 非住 宅では鉄筋コンクリート造（17\%），鉄骨造（26\%）が多くなる。 木造密集市街地といっても非木造化が一定程度進行していることが わかる。地区別にみても当然木造が大部分であるが, 工埸の多い神 楽地区の非住宅では木造（44\%)は少なく、鉄筋コンクリート造（20 \%)，鉄骨造（34\%）が主体となっている（表一3）。 表一-3 地区別震災前の構造
表一 2 地区別震㷋前の建物用途

棟数 (\%)

\begin{tabular}{|c|c|c|c|c|c|c|c|c|c|c|c|c|c|}
\hline & \multirow{3}{*}{$\begin{array}{l}\text { 専用 } \\
\text { 住宅 }\end{array}$} & \multicolumn{5}{|c|}{ 併用・併存住宅 } & \multicolumn{6}{|c|}{ 韭住 宅 } & \multirow{3}{*}{ 計 } \\
\hline & & \multicolumn{3}{|c|}{ 併用住宅 } & \multirow{2}{*}{ 併存 } & \multirow[t]{2}{*}{ 小計 } & \multirow[t]{2}{*}{ 店舗 } & \multirow[t]{2}{*}{ 工場 } & \multirow{2}{*}{$\begin{array}{c}\text { その } \\
\text { 他 }\end{array}$} & \multirow{2}{*}{ 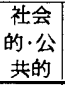 } & \multirow{2}{*}{ 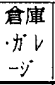 } & \multirow[t]{2}{*}{ 小計 } & \\
\hline & & 店舗 & 工埸 & $\left|\begin{array}{c}z \sigma \\
\text { 他 }\end{array}\right|$ & & & & & & & & & \\
\hline & 1414 & 103 & & 91 & 52 & 247 & 156 & 11 & 97 & 37 & 13 & 314 & \\
\hline & 1.6) & (5.2) & $(0.1)$ & (4.6) & (2.6) & (12.5) & $|(7.9)|$ & (0.6) & (4.9) & (1.9) & $(0.7)$ & $(15.9) \mid$ & \\
\hline 䄨策 & 642 & 83 & 71 & 40 & 58 & 262 & 103 & 237 & 127 & 14 & 31 & 511 & \\
\hline & (45.4) & (5.9) & (5.0) & (2.8) & (4.1) & (18.5) & (7.3) & (16.7) & (9.0) & (1.0) & (2.2) & $(36.1)$ & \\
\hline & 1593 & 119 & 21 & 64 & 178 & 382 & 167 & 24 & 48 & 19 & 21 & 279 & \\
\hline & & (5.3) & $(0.9)$ & (2.8) & (7.9) & (16.9) & (7.4) & (1.1) & (2.1) & $(0.8)$ & $(0.9)$ & $(12.4)$ & \\
\hline 梖管 & 2059 & 101 & 10 & 116 & 110 & 337 & 99 & & 50 & 25 & 2 & 183 & \\
\hline & $(79.8$ & (3.9) & $(0.4)$ & (4.5) & $(4.3)$ & $(1,3,1)$ & $(3,8)$ & $(0.3)$ & & $(1.0)$ & $(0.1)$ & (7.1) & \\
\hline 許 & 5708 & 406 & 103 & 311 & 408 & 1228 & 524 & 279 & 322 & 95 & $\begin{array}{r}67 \\
(08)\end{array}$ & 1287 & 8223 \\
\hline
\end{tabular}

\section{（2）建物階数}

建物階数は「 2 階建」 $78 \%$,「平屋」 $12 \%$,「 3 階建」 $6 \%$, 「4・5階建」 $3 \%$ ，「6階建以上」 $1 \%$ という分布で, 木造密集市街 地はほぼ2階建の建物で構成されている。

専用住宅, 併用・併存住宅, 非住宅の別にみると, 専用住宅で は，ほとんど (95\%) が2 階建までなのに比へ，併用・妍存住宅， 非住宅では3階建以上がそれぞれ20\%，26\%と相対的に多くなって いる。専用住宅について地区別に特徵をみると, 須磨, 芦屋の 2 地 区では「2 階建」が9 $2 \%, 89 \%$ と大半で, 戸建住宅地の特徵を示 している。神楽, 二葉地区については「2階建」は70\%,76\%と他 の 2 地区より低く，逆に「平屋」が2 $5 \% ， 20 \%$ と高い。これは，

震災以前には平屋長屋が多かったためである（表一4）。

\section{1 .3 建策時期}

全建物でみると「昭和 23 年以前」 $24 \%$,「昭和 $23 \sim 36$ 年」 $28 \%$, 「昭和36〜47年」18\%とほほ策 25 年以上が70\%と老朽化が進ん でいる。他方, 昭和 60 年以降という新しい建物は $5 \%$ いかない。尃 用住宅, 併用 - 併存住宅, 非住宅別にみても, 専用住宅では, 芦 屋, 神楽,二莱地区とも昭和 36 年以前の建物が多く,それぞれ $61 \%$, $79 \%, 71 \%$ となる。須磨地区は, 昭和 36 年以前の建物は $28 \%$ と少 棟数 (\%)

\begin{tabular}{|c|c|c|c|c|c|c|c|c|c|c|c|c|c|c|c|c|c|c|c|c|c|c|c|c|}
\hline & \multicolumn{6}{|c|}{ 専 用 住 宅 } & \multicolumn{6}{|c|}{ 併用・併存住宅 } & \multicolumn{6}{|c|}{ 非 住 宅 } & \multicolumn{6}{|c|}{ 計 } \\
\hline & 木造 & 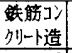 & 鉃骨造 & その他 & 不明 & 小計 & 木造 & 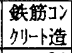 & 铁骨造 & その他 & 不明 & 小計 & 木造 & 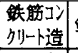 & 铁骨造 & その他 & 不明 & 小計 & 木造 & 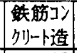 & 铁骨造 & その他 & 不明 & 垶 \\
\hline 芦星 & & $\begin{array}{r}70 \\
(5.0) \\
\end{array}$ & & $\begin{array}{r}3 \\
(0.2)\end{array}$ & 0 & & $\begin{array}{r}166 \\
(67.2)\end{array}$ & $\begin{array}{r}31 \\
(12.6) \\
\end{array}$ & \begin{tabular}{|r|}
47 \\
$(19.0)$
\end{tabular} & (1.2) & 0 & $\begin{array}{r}247 \\
100.0)\end{array}$ & $\begin{array}{r}196 \\
(62.4)\end{array}$ & \begin{tabular}{r|}
47 \\
$(15.0)$
\end{tabular} & \begin{tabular}{|r}
67 \\
$(21.3)$ \\
\end{tabular} & $\begin{array}{r}4 \\
(1.3)\end{array}$ & 0 & $\begin{array}{r}314 \\
(100.0)\end{array}$ & & $\begin{array}{r}148 \\
(7.5) \\
\end{array}$ & $\begin{array}{r}227 \\
(11.5)\end{array}$ & $\begin{array}{r}10 \\
(0.5)\end{array}$ & & \\
\hline 神桨 & 5 & 17 & 34 & 1 & 1 & 6 & 182 & 27 & 50 & 3 & 0 & 26 & 227 & 102 & 176 & 3 & 3 & & & 146 & 260 & 7 & 4] & \\
\hline & (91) & (2.6) & (5.3) & (0.2) & $(0.2)$ & $(100$. & (69.5) & (10.3) & (19.1) & (1.1) & & $(100.0$ & (44.4) & (20.0) & (34.4) & (0.6) & (0.6) & $(100$. & (70.5) & (10.3) & (18.4) & (0.5) & (0.3) & \\
\hline 二葉 & & $\begin{array}{r}11 \\
0\end{array}$ & 90 & 2 & 1 & & 295 & 31 & $\begin{array}{r}56 \\
72\end{array}$ & 0 & 0 & & $\begin{array}{r}173 \\
-620)\end{array}$ & & & 0 & 0 & 27 & & 100 & 194 & 2 & 1 & \\
\hline 㜥厢 & $\begin{array}{r}(93.5) \\
1895\end{array}$ & $\begin{array}{r}(0.7) \\
65\end{array}$ & $\begin{array}{r}(5.6) \\
98\end{array}$ & .1) & $\begin{array}{r}(0.1) \\
0\end{array}$ & $(100$ & (77.2) & $\begin{array}{r}(8.1) \\
33\end{array}$ & $\begin{array}{r}(14.7) \\
76\end{array}$ & & & 0.0. & $\begin{array}{r}(62.0) \\
126\end{array}$ & $\begin{array}{r}0.8) \\
17\end{array}$ & $\begin{array}{r}7.2) \\
38\end{array}$ & 2 & 0 & 183 & $\begin{array}{r}(86.8) \\
2246\end{array}$ & $\begin{array}{r}(4.4) \\
115\end{array}$ & $\begin{array}{r}(8.6) \\
212\end{array}$ & $\begin{array}{r}0.1) \\
5\end{array}$ & $\begin{array}{r}(0.0) \\
1\end{array}$ & \\
\hline & $(92.0)$ & (3.2) & (4.8) & $(0.0)$ & & & $(66.8)$ & (9.8) & (22.6) & $(0.6)$ & $(0.3)$ & $(100$ & (68.9) & (9.3) & $(20.8)$ & (1.1) & & & & (4.5) & (8.2) & $(0.2)$ & $(0.0)$ & \\
\hline 就 & & $\begin{array}{r}163 \\
(2.9)\end{array}$ & \begin{tabular}{r|}
335 \\
$(5.9)$
\end{tabular} & $\begin{array}{r}7 \\
(0.1)\end{array}$ & $\begin{array}{r}2 \\
(0.0)\end{array}$ & $\begin{array}{r}5708 \\
(100.0)\end{array}$ & $\begin{array}{r}868 \\
(70.7) \\
\end{array}$ & \begin{tabular}{r|}
122 \\
$(9.9)$
\end{tabular} & $\begin{array}{r}229 \\
(18.6)\end{array}$ & $\begin{array}{r}8 \\
(0.7)\end{array}$ & $\begin{array}{r}1 \\
(0.1)\end{array}$ & $\begin{array}{r}1228 \\
(100.0)\end{array}$ & $\begin{array}{r}722 \\
(56.1)\end{array}$ & \begin{tabular}{r|}
224 \\
$(17.4)$
\end{tabular} & $\begin{array}{r}329 \\
(25.6) \\
\end{array}$ & & $\begin{array}{r}3 \\
.2)\end{array}$ & & & & & 24 & 66 & \\
\hline
\end{tabular}

表一 4 地区別震苂前の建物階数

\begin{tabular}{|c|c|c|c|c|c|c|c|c|c|c|c|c|c|c|c|c|c|c|c|c|c|c|c|c|c|c|c|c|}
\hline & \multicolumn{3}{|r|}{ 尃 } & \multicolumn{4}{|c|}{ 用住害 } & \multicolumn{7}{|c|}{ 併用 $\cdot$ 併存住宅 } & \multicolumn{7}{|c|}{ 非 住 宅 } & \multicolumn{7}{|c|}{$\begin{array}{l}\text { 計 } \\
\end{array}$} \\
\hline & 平琣 & $\begin{array}{c}2 \text { 2階 } \\
\text { 建 }\end{array}$ & $\begin{array}{c}\text { 階 } \\
\text { 建 }\end{array}$ & \begin{tabular}{|l|l|}
$4 \cdot 5$ \\
階建 \\
\end{tabular} & $\begin{array}{l}68 \text { 隕 } \\
\text { 以上 }\end{array}$ & 不明 & 小計 & 平厒 & $\begin{array}{c}2 \text { 㻸 } \\
\text { 等 }\end{array}$ & 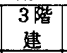 & \begin{tabular}{|l|}
$4 \cdot 5$ \\
階建 \\
\end{tabular} & \begin{tabular}{|l|}
6 㻸 \\
以上
\end{tabular} & 不明 & 小尌 & 平屋 & 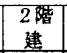 & $\begin{array}{c}\begin{array}{c}3 \text { 階 } \\
\text { 建 }\end{array} \\
\end{array}$ & \begin{tabular}{|l|}
$4 \cdot 5$ \\
階建 \\
\end{tabular} & $\begin{array}{l}6 \text { 㻸 } \\
\text { 以上 }\end{array}$ & 不明 & 小竐 & 平屋 & $\begin{array}{l}\text { 2階 } \\
\text { 建 }\end{array}$ & $\begin{array}{l}\text { 留 } \\
\text { 建 }\end{array}$ & $\begin{array}{l}4 \cdot 5 \\
\text { 階建 }\end{array}$ & $\begin{array}{l}6 \text { 階 } \\
\text { 以上 } \\
\end{array}$ & 不明 & 計 \\
\hline 芦屋 & $\begin{array}{r}59 \\
(4.2)\end{array}$ & \begin{tabular}{|r|}
1260 \\
$(89.1)$ \\
\end{tabular} & $\begin{array}{r}59 \\
(4.2)\end{array}$ & $\begin{array}{r}31 \\
(2.2)\end{array}$ & $\begin{array}{r}5 \\
(0.4)\end{array}$ & 0 & $\begin{array}{r}1414 \\
(100.0)\end{array}$ & $\begin{array}{r}10 \\
(4.0)\end{array}$ & $\begin{array}{r}180 \\
(72.9)\end{array}$ & \begin{tabular}{|r|}
26 \\
$(10.5)$
\end{tabular} & $\begin{array}{r}27 \\
(10.9)\end{array}$ & $\begin{array}{r}4 \\
(1.6)\end{array}$ & 0 & $\begin{array}{r}247 \\
(100.0)\end{array}$ & $\begin{array}{r}47 \\
(15.0) \\
\end{array}$ & \begin{tabular}{|r|}
209 \\
$(66.6)$
\end{tabular} & $\begin{array}{r}39 \\
(12.4) \\
\end{array}$ & $\begin{array}{r}15 \\
(4.8)\end{array}$ & $\begin{array}{r}3 \\
(1.0)\end{array}$ & $\begin{array}{r}1 \\
(0.3)\end{array}$ & $\begin{array}{r}314 \\
(100.0)\end{array}$ & $\begin{array}{r}116 \\
(5.9)\end{array}$ & $\begin{array}{r}1649 \\
(83.5) \\
\end{array}$ & $\begin{array}{r}124 \\
(6.3)\end{array}$ & $\begin{array}{r}73 \\
(3.7)\end{array}$ & $\begin{array}{r}12 \\
(0.6)\end{array}$ & $(0.1)$ & $\begin{array}{r}1975 \\
(100.0)\end{array}$ \\
\hline 神楽 & 158 & 447 & 20 & 12 & 4 & 1 & 642 & 35 & 169 & ro & 21 & 4 & 0 & 262 & 73 & 261 & 88 & 77 & 10 & 2 & 511 & 266 & 877 & 141 & 110 & 18 & 3 & 1415 \\
\hline & (24.6) & $(69.6)$ & (3.1) & (1.9) & (0.6) & $(0.2)$ & $(100.0)$ & $(13.4)$ & $(64.5)$ & (12.6) & $(8.0)$ & (1.5) & & $(100.0)$ & (14.3) & (51.1) & $(17.2)$ & $(15.1)$ & $(2.0)$ & $(0.4)$ & $(100.0)$ & (18.8) & $(62.0)$ & (10.0) & (7.8) & (1.3) & $(0.2)$ & $(100.0)$ \\
\hline 二蒾 & 319 & 1211 & 49 & 10 & 2 & 2 & 1593 & 48 & 274 & \begin{tabular}{|l|}
39 \\
\end{tabular} & 19 & 2 & 0 & $\quad 382$ & 41 & 166 & \begin{tabular}{|l|}
$\mid$ \\
$\mid$
\end{tabular} & 3 & 7 & 0 & 279 & 408 & 1651 & 150 & 32 & 11 & 2 & 2254 \\
\hline & $(20.0)$ & $(76.0)$ & $|(3.1)|$ & $(0.6)$ & $(0.1)$ & (0.1) & $(100.0)$ & (12.6) & $\mid(71.7)$ & $(10.2)$ & (5.0) & $(0.5)$ & & $(100.0)$ & $(14.7)$ & (59.5) & $(22.2)$ & (1.1) & (2.5) & & $(100.0)$ & (18.1) & (73.2) & (6.7) & (1.4) & (0.5) & $(0.1)$ & $(100.0)$ \\
\hline 須䄷 & 101 & 1884 & 47 & 19 & 7 & 1 & 2059 & 20 & $\begin{array}{r}246 \\
\end{array}$ & 38 & 20 & 12 & 1 & 337 & 34 & 125 & 14 & 9 & 1 & 0 & 183 & $\begin{array}{r}155 \\
600\end{array}$ & 2255 & 99 & 48 & 20 & 2 & 2579 \\
\hline & (4.9) & (91.5) & $(2.3)$ & $(0.9)$ & $(0.3)$ & $(0.0)$ & $(100.0)$ & (5.9) & $(73.0)$ & (11.3) & (5.9) & (3.6) & $(0.3)$ & $(100.0)$ & $(18.6)$ & $(68.3)$ & (7.7) & (4.9) & $(0.5)$ & & $(100.0)$ & (6.0) & $(87.4)$ & (3.8) & (1.9) & $(0.8)$ & $(0.1)$ & $(100.0)$ \\
\hline 就 & $\begin{array}{r}637 \\
(11.2) \\
\end{array}$ & \begin{tabular}{|r|}
4802 \\
$(84.1)$ \\
\end{tabular} & \begin{tabular}{|r|}
175 \\
$(3.1)$ \\
\end{tabular} & $\begin{array}{r}72 \\
(1.3) \\
\end{array}$ & $\begin{array}{r}18 \\
(0.3)\end{array}$ & $\begin{array}{r}4 \\
(0.1)\end{array}$ & $\begin{array}{r}5708 \\
(100.0)\end{array}$ & $\begin{array}{r}113 \\
(9.2) \\
\end{array}$ & \begin{tabular}{|r|}
869 \\
$(70.8)$ \\
\end{tabular} & $\begin{array}{r}136 \\
(11.1) \\
\end{array}$ & $\begin{array}{r}87 \\
(7.1) \\
\end{array}$ & $\begin{array}{r}22 \\
(1.8) \\
\end{array}$ & $\begin{array}{r}1 \\
(0.1)\end{array}$ & $\begin{array}{r}1228 \\
(100.0)\end{array}$ & $\begin{array}{r}195 \\
(15.2) \\
\end{array}$ & \begin{tabular}{|r|}
761 \\
$(59.1)$ \\
\end{tabular} & $\begin{array}{r}203 \\
(15.8)\end{array}$ & $\begin{array}{r}104 \\
(8.1)\end{array}$ & \begin{tabular}{r|}
21 \\
$(1.6)$
\end{tabular} & $\begin{array}{r}3 \\
(0.2) \\
\end{array}$ & $\begin{array}{r}1287 \\
(100.0)\end{array}$ & $\begin{array}{r}945 \\
(11.5) \\
\end{array}$ & $\begin{array}{r}6432 \\
(78.2) \\
\end{array}$ & $\begin{array}{r}514 \\
(6.3)\end{array}$ & \begin{tabular}{|r|}
263 \\
$(3.2)$ \\
\end{tabular} & $\begin{array}{r}61 \\
(0.7)\end{array}$ & $\begin{array}{r}8 \\
(0.1)\end{array}$ & $\begin{array}{r}8223 \\
(100.0)\end{array}$ \\
\hline & 表 & & 地 & 刉雲 & $\{\leq$ & $D 3$ & 物及 & 時其 & & & & & & & & & & & & & & & & & & & $(\%$ & \\
\hline
\end{tabular}

\begin{tabular}{|c|c|c|c|c|c|c|c|c|c|c|c|c|c|c|c|c|c|c|c|c|c|c|c|c|c|c|c|}
\hline & \multirow{2}{*}{\multicolumn{7}{|c|}{ 専 角 住 宅 }} & \multirow{2}{*}{\multicolumn{7}{|c|}{ 併用 - 併存住空 }} & \multirow{2}{*}{\multicolumn{6}{|c|}{ 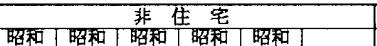 }} & \multicolumn{7}{|c|}{ 計 } \\
\hline & 眧和 & & & & & & & 昭和 & & & & & & & & & & & & & 昭和 & 眧和 & 名和 & 昭和 & 召和 & & \\
\hline & 23年 & $23 \sim$ & $36 \sim$ & $47 \sim$ & 60年 & 不明 & 小詰 & 23年 & $23 \sim$ & $36 \sim$ & $47 \sim$ & 60年 & 不明 & 小計 & 23年 & $23 \sim$ & $36 \sim$ & $47 \sim$ & 60年 & 小計 & 23年 & $23 \sim$ & $36 \sim$ & $47 \sim$ & 0年 & 明 & 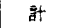 \\
\hline & 以新 & 36年 & 47年 & 60年 & 以隆 & & & 以前 & 36年 & 47年 & 60年 & & & & & 36年 & 47年 & 60年 & & & & 36年 & 47年 & 60年 & 以降 & & \\
\hline 芦屋 & 157 & 701 & \begin{tabular}{|r|}
308 \\
\end{tabular} & 205 & 41 & & 1414 & 15 & 112 & \begin{tabular}{|l|}
59 \\
\end{tabular} & 55 & & 0 & 247 & 17 & 159 & 70 & 56 & 12 & 314 & 189 & 972 & 437 & 316 & 59 & & 87 \\
\hline & 1.1) & (49.6) & (21.8) & (14.5) & (2.9) & .1) & $.00 .0)$ & (6.1) & (45.3) & (23.9) & (22.3) & (2.4) & & $(100.0)$ & (5.4) & (50.6) & $|(22.3)|$ & (17.8) & (3.8) & $(100.0)$ & (9.6) & (49.2) & (22.1) & $(16.0)$ & .0) & .1) & \\
\hline 神楽 & 58 & 449 & 54 & 70 & 11 & 0 & & 27 & 122 & 32 & \begin{tabular}{|r|} 
\\
\end{tabular} & 18 & 0 & 262 & 72 & 154 & 92 & 147 & 46 & & 157 & \begin{tabular}{|l|}
225 \\
\end{tabular} & 178 & 280 & 5 & 0 & \\
\hline & (9.0) & (69.9) & (8.4) & (10.9) & (1.7) & & $(100.0)$ & (10.3) & (46.6) & (12.2) & $|(24.0)|$ & (6.9) & & $(100.0)$ & (14.1) & (30.1) & $(18.0)$ & (28.8) & (9.0) & $(100.0)$ & (11.1) & (51.2) & (12.6) & (19.8) & $(5.3)$ & & \\
\hline 二菓 & 993 & 144 & 238 & 162 & 56 & 0 & & 244 & 22 & & 48 & 15 & 1 & 382 & {$[154$} & 13 & 82 & 23 & 7 & & 1391 & 179 & 372 & & 8 & 1 & \\
\hline & (62.3) & (9.0) & $|(14.9)|$ & (10.2) & (3.5) & & (100 & (63.9) & (5.8) & (13.6) & (12.6) & (3.9) & (0.3) & $(100.0)$ & (55.2) & (4.7) & $|(29.4)|$ & (8.2) & (2.5) & $(100.0)$ & $(61.7)$ & (7.9) & (16.5) & (10.3) & (3.5) & $(0.0)$ & \\
\hline 碩犘 & 224 & 354 & 382 & 959 & 137 & & 2059 & 31 & 67 & 49 & 148 & 41 & 1 & 337 & 17 & 35 & 29 & 82 & 20 & 183 & 272 & 456 & 460 & 1189 & 98 & 4 & \\
\hline & (10.9) & $(17.2)$ & (18.6), & (46.6) & (6.7) & $(0.1)$ & (100 & (9.2) & (19.9) & (14.5) & (43.9) & (12.2) & $(0.3)$ & $(100.0)$ & (9.3) & (19.1) & $(15.8)$ & $(44.8)$ & (10.9) & & (10.5) & (17.7) & (17.8) & (46.1) & (7.7) & $(0.2)$ & \\
\hline
\end{tabular}


表一 6 地区別震災前の住宅形式

\begin{tabular}{|c|c|c|c|c|c|c|c|c|c|c|c|c|}
\hline & \multicolumn{6}{|c|}{ 棟 } & \multicolumn{6}{|c|}{ 数 } \\
\hline & 戸建 & 長屋 & $\begin{array}{l}\text { 文化. } \\
\text { 分ハ八 } \\
-ト\end{array}$ & $\begin{array}{l}\text { マン } \\
\text { ショ } \\
\text { シ }\end{array}$ & 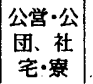 & 計 & ·建 & 長屋 & $\begin{array}{l}\text { 文化. } \\
3 ハ 0 \\
-ト\end{array}$ & $\begin{array}{l}\text { マン } \\
\text { ショ }\end{array}$ & $\begin{array}{l}\text { 公営·公 } \\
\text { 团.社 } \\
\text { 宅·费 }\end{array}$ & 部 \\
\hline 芦幄 & 1438 & 35 & 78 & .99 & . 11 & 1661 & 1438 & 120 & 363 & 1276 & 181 & 3378 \\
\hline & (86.6 & (2.1) & (4.7) & (6.0) & $(0: 7)$ & $(100.0)$ & |(42.6) & (3.6) & $(10.7)$ & (37.8) & (5.4) $\mathrm{k}$ & $(100$ \\
\hline 神楽 & 752 & 80 & 33 & 35 & & 905 & $\begin{array}{l}752 \\
\end{array}$ & 227 & 180 & \begin{tabular}{|l|}
567 \\
\end{tabular} & 290 & 2016 \\
\hline & $(83.1)$ & (8.8) & (3.6) & (3.9) & $(0.6)$ & $(100.0)$ & $\mid(37.3)$ & (11.3) & (8.9) & $\mid(28.1)$ & (14.4) $\mathrm{x}$ & $(100$. \\
\hline 二莱 & 1389 & 410 & 143 & 31 & & 1975 & 1389 & 1107 & 453 & 343 & 21 & 33 \\
\hline & (70.3) & $(20.8)$ & (7.2) & (1.6) & $(0.1)$ & $(100.0)$ & (41.9) & (33.4) & $(13.7)$ & (10.4) & $(0.6) k$ & $(100.0)$ \\
\hline 須磨 & 1973 & 189 & 146 & 70 & 18 & & \begin{tabular}{|l|} 
\\
\end{tabular} & 480 & 694 & \begin{tabular}{|l|}
1153 \\
\end{tabular} & 785 & 50 \\
\hline & (82.3) & $(7.9)$ & (6.1) & (2.9) & $(0.8)$ & $(100.0$ & (38.8) & (9.4) & $(13.6)$ & (22.7) & (15.4)k & $(100.0)$ \\
\hline 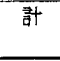 & $\begin{array}{r}5552 \\
(80.0) \\
\end{array}$ & $\begin{array}{r}714 \\
(10.3) \\
\end{array}$ & $\begin{array}{r}400 \\
(5.8) \\
\end{array}$ & $\begin{array}{r}235 \\
(3.4) \\
\end{array}$ & $\begin{array}{r}36 \\
(0.5) \\
(\end{array}$ & $\begin{array}{r}6937 \\
(100.0) \\
\end{array}$ & \begin{tabular}{|c|}
5552 \\
$(40.3)$ \\
\end{tabular} & $\begin{array}{c}194 \\
(14.0)\end{array}$ & $\begin{array}{l}1690 \\
(12.3)\end{array}$ & \begin{tabular}{|r|}
3339 \\
$(24.2)$ \\
\end{tabular} & \begin{tabular}{|c|}
127 \\
$(9.3)$
\end{tabular} & $\begin{array}{r}13792 \\
(100: 0)\end{array}$ \\
\hline
\end{tabular}

なく，「昭和 $47 \sim 60$ 年」が $47 \%$ と相対的に多くて，建築時期が比 較的新しい。この時期は，ミ三開発による狭小住宅が多く建てられ た時期であり，須磨地区でもそうした住宅で被害が大きかっだ 7)。二葉地区は，建築時期からわかるように戦前の長屋住宅が多く 残っている地区である。并用・并存住宅，非住宅は，専用住宅と同 じ傾向を示すが，若干建策時期が新しい（表一 5 ）。

\section{2 住宅の状況}

震災前の住宅について，住宅形式別に戸数，棟数でみる（表一 6)。木造密集市街地といっても住宅は, 棟数（建物単位）でタる のと戸数（世带単位）でみるのとではかなり状況がちがう。

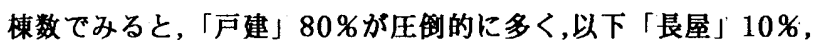
「文化・アパート」 $6 \%$ ，「マンション」3\%，「公営・公団・社 宅・寮等」0.5\%の順である。「戸建」が80\%を占め，木造密集市 街地はまさに木造戸建住宅の市街地となる。しかし戸数でみると 「戸建」 $40 \%$ ，「長屋」 $14 \%$ ，「文化・アパート」 $12 \%$ ，「マン ション」 $24 \%$,「公党・公団・社宅・寮等」9\%となり, マンショ ンを含む集合住宅の住戸が多くなる。

これを地区別でみると，芦屋，神楽地区は「戸建」についで「マ ンション」が多く，二葉地区は「戸建」「長屋」が多くなる。須磨 地区は「戸建」を主にしながら「マンション」「文化・アパート」

「公営・公団・社宅・然等」が混在している。

このことから，二葉，神楽地区は，戸建とともに屒屋が多い古い 都市型住宅地, 芦屋地区は戸建の多い刘外型住宅地, 須磨地区は, 文化・アパートも多く，芦屋地区と二葉・神楽地区の中間的な住宅 地となっている。ただし，戸数でみるかぎり，二莱地区を除いた 3 地区とも，マンションで代表される集合住宅が增えており，戸建住 宅中心の木造密集住宅地が瓷化してきていることがわかる。

\section{4．木造密集市街地建物の被災度}

木造密集市街地で，被害を拡大させた原因は，地震の大きさ（播 れ）のほかに，建物条件も大きな要因と考えられる。ここでは，非 住宅を含めた全建物について，地区別に被災度をみたあと，建物要 因として，建物用途，構造，建築時期との関係で被災度を分析す る。被災度は, 全焼, 全坡, 半埭, 小破, 無傷の 5 段階とする。

\section{1 地区からみた被災度}

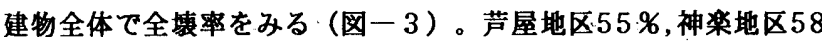
\%, 二葉地区 $19 \%$, 須磨地区 $34 \%$ である。半填とあわせてみると, 芦屋地区70\%, 神楽地区70\%，二葉地区 $40 \%$ ，須店地区72\%とな り，それに神楽地区，二葉地区では全焼の各 $13 \%, 11 \% か ゙$ 加わる。 被害の大きい順に, 神楽地区, 芦屋地区, 須磨地区, 二葉地区とな る。神楽，芦屋地区では過半数が全塿という大きな被害を，須磨地

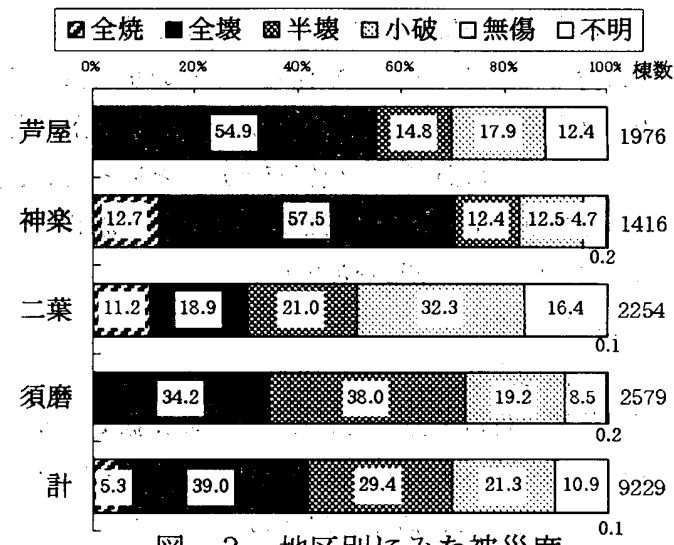

図一－＂地区別にみた被災度

\begin{tabular}{l}
\multicolumn{9}{c}{ 表一7 建物用途からみた被災度 } \\
\hline
\end{tabular}

区でも全・半垶が $3 / 4$ という大きな被害となっている。これら 3 地区に比べると二葉地区ての被害は相対的には小さい。

\section{2 建物要因からみた被災度}

\section{2 .1 建物用途からみた被災度}

建物用途で被害をみると，専用住宅では，全坡（40\%）が最も高 く，半軖（25\%），小破（21\%），無傷（11\%）となる。併用"・ 併存住宅，非住宅とも，専用住宅とほぼ同じ㑯向を示す。ただ非住

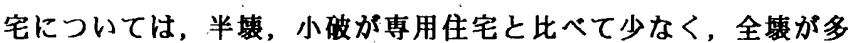
い。とくに工埸咞用住宅で全塿（53\%）が多いが，これはケミカル 工坦の多い神楽地区での被害が大きかったためである（表一7）。

\section{2 .2 構造別被災度}

全建物で全坡率をみると，木造（44\%），鉄骨造（22\%）， R C造（9 \%) となり，木造の被害が大きいことがわかる。半填をあ わせると木造の被害は68\%となり，逆に鉄骨造， R C 造の小破，無 傷という被害のない部分をあわせた，それぞれ5 5\%，68\%と比較 すると㻮だった対照をみせている。これを住宅，併用・併存住宅，

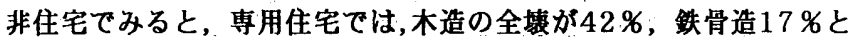
なる。并用・併存住宅では，全棲が木造 $44 \%$, 鉄骨造 $18 \%$ と専用 住宅よりも高く，全塿，半塿をあわせてみても専用住宅より高い。 次に非住宅をみると全坡が木造 $54 \%$ ，鉄骨造 $29 \%$ 小，R C造 $13 \%$ となり， R C 造の被害が相対的に大きくなっている。これも神楽地 区の被害が大きいことが主な理由である（表- 8）。

\section{2 .3 建築時期別被災度}

建築時期と被災度の関係をみた結果が表ー9である。全建物でみ ると, 昭和 23 年以降に建策された住宅では, 全埢率で「昭和 $23 \sim$ 
表一8 構造からみた被災度

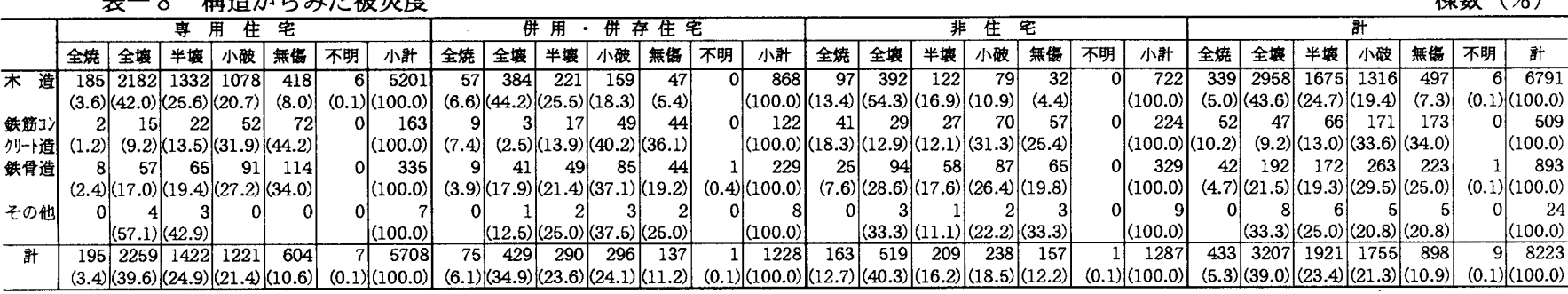

表一 9 建築時期からみた被災度

棟数 $(\%)$

\begin{tabular}{|c|c|c|c|c|c|c|c|c|c|c|c|c|c|c|c|c|c|c|c|c|c|c|c|c|c|c|c|c|}
\hline & \multicolumn{7}{|c|}{ 䙳用住宅 } & \multicolumn{7}{|c|}{ 竍用・讲存住宅 } & \multicolumn{7}{|c|}{ 非住 宅 } & \multicolumn{7}{|c|}{ 計 } \\
\hline & 全焼 & 全淁 & 半壤 & 小破 & 無镯 & 不明 & 小計 & 全焼 & 全蝔 & 半壤 & \begin{tabular}{|l|} 
小破 \\
\end{tabular} & 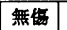 & 不明 & 小計 & 全焼 & 全墑 & 半壤 & 小破 & 無侮 & 不明 & 小訪 & 全焼 & 全壊 & 半壞 & 小破 & 無傹 & 不明 & 計 \\
\hline 昭和 23 & 94 & 492 & 308 & 385 & 153 & 0 & 1432 & 35 & 102 & 85 & 70 & 25 & 0 & 317 & 66 & 88 & 44 & 37 & 25 & 0 & 259 & 195 & 682 & 437 & 492 & 203 & 0 & 2008 \\
\hline 年以前 & (6.6) & $\mid(34.4)$ & (21.5) & $(26.9)$ & (10.7) & & $(100.0)$ & $(11.0)$ & $(32.2)$ & $(26.8)$ & (22.1) & (7.9) & & $(100.0)$ & $(25.5) \mid$ & $(34.0)$ & $(17.0)$ & (14.3) & (9.7) & & $(100.0)$ & (9.7) & $(34.0) \mid$ & (21.8) & (24.5) & (10.1) & & $(100.0)$ \\
\hline 昭和 23 & 70 & 938 & $\mid 297$ & 228 & {$\left[\begin{array}{r}111 \\
\end{array}\right.$} & 4 & {$\left[\begin{array}{r}1648 \\
\end{array}\right.$} & {$\left[\begin{array}{r}17 \\
{[}\end{array}\right.$} & 191 & 60 & 40 & 15 & 0 & 323 & 30 & {$\left[\begin{array}{r}231 \\
23\end{array}\right.$} & {$\left[\begin{array}{r}42 \\
\end{array}\right.$} & 38 & 19 & 1 & 361 & 117 & 1360 & 399 & 306 & 145 & 5 & 2332 \\
\hline$\sim 36$ 年 & (4.2) & $(56.9)$ & $(18.0)$ & (13.8) & (6.7) & (0.2) & $(100.0)$ & (5.3) & $(59.1)$ & $(18.6)$ & $(12.4)$ & (4.6) & & $(100.0)$ & $(8.3)$ & $(64.0)$ & (11.6) & $(10.5)$ & (5.3) & $(0.3)$ & $(100.0)$ & (5.0) & (58.3) & $(17.1)$ & (13.1) & (6.2) & $(0.2)$ & $(100.0)$ \\
\hline 昭和 36 & 17 & 377 & 303 & 203 & 82 & 0 & 982 & 7 & 63 & \begin{tabular}{|r|r|} 
& 35 \\
\end{tabular} & 57 & 30 & 0 & 192 & 46 & \begin{tabular}{|l|} 
\\
\end{tabular} & 46 & $\quad 55$ & \begin{tabular}{|r|} 
\\
\end{tabular} & 0 & $\quad 272$ & 70 & $527 \mid$ & 384 & 315 & 151 & 0 & 1446 \\
\hline$\sim 47$ 年 & (1.7) & $(38.4)$ & $(30.9)$ & $(20.7)$ & (8.4) & & $(100.0)$ & (3.6) & $(32.8)$ & $(18.2)$ & $(29.7) \mid$ & (15.6) & & $(100.0)$ & $(16.9)$ & $(32.0)$ & (16.9) & $\mid(20.2)$ & (14.3) & & $(100.0)$ & (4.8) & (36.4) & $\mid(26.6)$ & $|(21.8)|$ & (10.4) & & $(100.0)$ \\
\hline 昭和 47 & 14 & 428 & 457 & 334 & 161 & 2 & 1396 & 14 & 66 & 86 & 93 & $\begin{array}{l}55 \\
\end{array}$ & 0 & $\begin{array}{l}314 \\
\end{array}$ & 17 & 88 & 64 & 79 & 60 & 0 & 309 & 45 & 582 & 607 & \begin{tabular}{|l|}
506 \\
\end{tabular} & 276 & 2 & 2019 \\
\hline$\sim 60$ 年 & (1.0) & $(30.7)$ & (32.7) & (23.9) & (11.5) & $(0.1)$ & $(100.0)$ & (4.5) & $(21.0)$ & $(27.4)$ & $(29.6)$ & (17.5) & & $(100.0)$ & (5.5) & $(28.5)$ & $(20.7)$ & $(25.6)$ & (19.4) & & $(100.0)$ & (2.2) & (28.8) & $(30.1)$ & (25.1) & $(13.7)$ & $(0.1)$ & $(100.0)$ \\
\hline 昭和 60 & & 22 & 57 & 71 & 94 & & $\begin{array}{l}245 \\
\end{array}$ & & 7 & 23 & 36 & \begin{tabular}{|}
12 \\
\end{tabular} & 0 & & & $\begin{array}{r}25 \\
\end{array}$ & 13 & 29 & 14 & 0 & & 6 & 54 & 93 & 136 & 120 & 1 & 411 \\
\hline 年以降 & $(0.0)$ & $(9: 0)$ & $(23.3)$ & $(29.0)$ & (38.4) & $(0.4)$ & $(100.0)$ & (2.5) & $(8.8)$ & $(28.8)$ & $(45.0)$ & $(15.0)$ & & $(100.0)$ & $(4.7)$ & $(29.1)$ & (15.1) & $(33.7)$ & (16.3) & & $(100.0)$ & (1.5) & (13.1) & $(22.6)$ & (33.1) & $(29.2)$ & $(0.2)$ & $(100.0)$ \\
\hline 計 & $\begin{array}{r}195 \\
(3.4)\end{array}$ & \begin{tabular}{|r|}
2259 \\
$(39.6)$ \\
\end{tabular} & $\begin{array}{l}1422 \\
(24.9)\end{array}$ & \begin{tabular}{|l|}
1221 \\
$(21.4)$ \\
\end{tabular} & $\begin{array}{r}604 \\
(10.6)\end{array}$ & $\begin{array}{r}7 \\
(0.1)\end{array}$ & $\begin{array}{r}5708 \\
(100.0)\end{array}$ & $\begin{array}{r}75 \\
(6.1)\end{array}$ & \begin{tabular}{|r|}
429 \\
$(34.9)$ \\
\end{tabular} & $\begin{array}{r}290 \\
(23.6) \\
\end{array}$ & $\begin{array}{r}296 \\
(24.1) \\
\end{array}$ & $\begin{array}{r}137 \\
(11.2)\end{array}$ & $\begin{array}{r}1 \\
(0.1)\end{array}$ & \begin{tabular}{|r|}
1228 \\
$(100.0)$
\end{tabular} & \begin{tabular}{|r|}
163 \\
$(127)$ \\
\end{tabular} & $\begin{array}{r}519 \\
(40.3) \\
\end{array}$ & \begin{tabular}{|r|}
209 \\
$(16.2)$
\end{tabular} & \begin{tabular}{|r|}
238 \\
$(18.5)$ \\
\end{tabular} & $\begin{array}{r}157 \\
(12.2) \\
\end{array}$ & $\begin{array}{r}1 \\
(0.1)\end{array}$ & $\begin{array}{r}1287 \\
(100.0)\end{array}$ & $\begin{array}{r}433 \\
(5.3) \\
\end{array}$ & \begin{tabular}{|c|}
3207 \\
$(39.0)$
\end{tabular} & $\begin{array}{c}1921 \\
(23.4) \\
\end{array}$ & \begin{tabular}{|l|}
1755 \\
$(21.3)$ \\
\end{tabular} & $\begin{array}{r}898 \\
(11.9) \\
\end{array}$ & $\begin{array}{r}9 \\
(0.1)\end{array}$ & $\begin{array}{r}8223 \\
(100.0)\end{array}$ \\
\hline
\end{tabular}

36 年」の $58 \%$ から「昭和 60 年以降」の $13 \%$ まで直線的に明確に相 関している。しかし「昭和 23 年以前」という最も古い時期について は次の時期のものより全塤率（34\%)が小さい。これは,最も被害が 少なかった二菓地区で「昭和 23 年以前」の建物割合が多いこと( 4 地区で260戸に対して二葉地区が154戸、表-4参照）が原因してい る。専用住宅, 併用・併存住宅, 非住宅でみると, 専用住宅では, 全填率が「昭和 $23 \sim 36$ 年」の57\%，「昭和36〜 47年」38\%となり 全建物と同じ傾向を示している。併用・妍存住宅も, 同じ㑯向を示 すが，非住宅では「昭和 60 年以降」の新しい建物で,全埩（29\%） が高いのがめだっている。

\section{5. 住宅被害の実態と構造}

前章では，市街地建物について専用住宅，垪用・併存住宅, 非住 宅でみてきたが, 本章では被害の中心になる住宅について, 住宅形 式，構造，建筑時期等との関係で住宅被害の実熊を分析する。なお 市街地建物では，「全焼」を含めて分析してきたが，本章では，よ り被害実熋を明碓にするため，建物の損填度がわからない「全焼」 データを除外して分析する。

\section{1 住宅形式からみた被害の実態}

棟数で全塤率をみると「戸建」 $41 \%$ ，「屒屋」 $42 \%$ ，「文化・ アパート」44\%,「マンション」 $20 \%$,「公営・公団・社宅・寮等」 $26 \%$ となる。「文化・アパート」で全嘈率が最も高いのは古い建物 が多いことによるものである。また, 全塿, 半塿あわせてみると 「戸建」 $67 \%$ ，「長屋」 $70 \%$ ，「文化・アパート」 $71 \%$ と木造が 大半を占める住宅形式に被害が集中している。一方, 戸数でみると 「長屋」「文化・アパート」は棟数と同じ㑯向を示すが「マンショ ン」「公営・公団・社宅・寮等」については被害が小さくなってい る。これらの住宅タイプでは小規模棟の方が相対的に被害が大き かったことがわかる（表一10）。

\section{2 住宅被害の要因分析}

\section{2 .1 構造, 建築時期からみた被災度}

被害の大半を木造が占めることが一連の分析でわかったことか ら、ここでは，木造住宅の被害をより明確に把挃するため構造を ペースに地区別，建築時期別に被災度を分析する（図一4）。

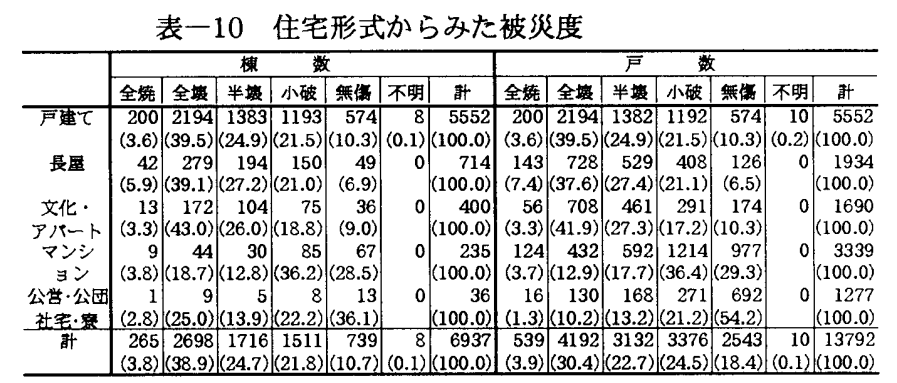

木造の全罣率をみると，神楽地区が最もひどく，昭和 47 年以前の 建物では全塤率は 8 割をこえる。「昭和 $47 \sim 60$ 年」の建物でも過半 数 (54\%) が全識，9割以上 (93\%) が全・半塤で，「60年以降」 ではじめて, 全埭率（15\%）が小さくなる。芦屋地区も神楽地区に ついで被害が大きく，昭和 47 年以前の建物では過半数が全壊してい る。須唐地区はこれら 2 地区よりは被害が小さいが，それでも「昭

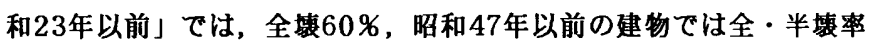
90 \%以上と被害は大きい。これら被害の大きい 3 地区では, 建築年 代が新しくなるのに比例して相対的に被害は小さくなっている。し かし, 全・半羁率が小さく被害が少なくなるのは, 昭和 60 年以降に 建築された住宅だけである。これら 3 地区に比べると震度 6 の二莱 地区での被害はかなり小さい。昭和 47 年以前のもので, 全坡率 $20 \%$

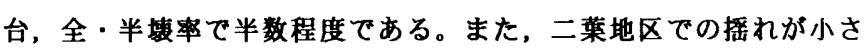
かったためと思われるが, 昭和 47 年より以前の各時期については, 建築時期による被害の差はみられない。

木造とは逆にR C 造による被害は小さい。被害のあるのは, 芦屋 地区（昭和 $23 \sim 36$ 年, $36 \sim 47$ 年），神楽地区（昭和 23 年以前）， 二葉地区（昭和 $36 \sim 47$ 年），須婼地区（昭和 23 年 36年, $36 \sim 47$ 年）といった古い住宅である。

鉄骨造の被害はその中間にある。全埭率でみると、神楽地区（43 \%)，芦屋地区（34\%）では被害が大きく，二葉，須磨地区は小さ い。また鉄骨造の被害は建築時期による㑯向はみられず被害はバラ ついている。このことから鉄骨造の被害は, 第 1 には, 地区差とし て現われている地震動による搂れの違いであり，第 2 には，建築の 古さよりも施工の良否等建築の質によるものと思われる。

5.2 .2 住宅形式・建築時期からみた木造住宅の被災度

本項では，被害の中心である木造住宅だけを対象にして，住宅形 
式をベ一スに地区別，建築時期別に被災度を分析する（図一5）。

住宅形式別の全垻率，全・半墥率をみると，文化・アパート（49 \%。79\%)，長屋 $(42 \% ， 71 \%) ，$ 戸建 $(44 \%, 70 \%)$ であり, 文化・アパートが最も被害が大きい。長屋と戸建は同程度にみえる が,これは被害の少ない二莱地区で長屋の割合が大きい（4地区
1,706戸に対して960戸) ためであり、このことを差し引いて考え ると被害は，良屋, 户建の順になる。

次に地区別に梏住宅の被害を考察する。最も被害の大きい神楽 地区では，文化・アパート，長屋は，一部新しいものに半坡がみら れるが，ほほ全城である。戸建住宅についても，昭和60年以前の住

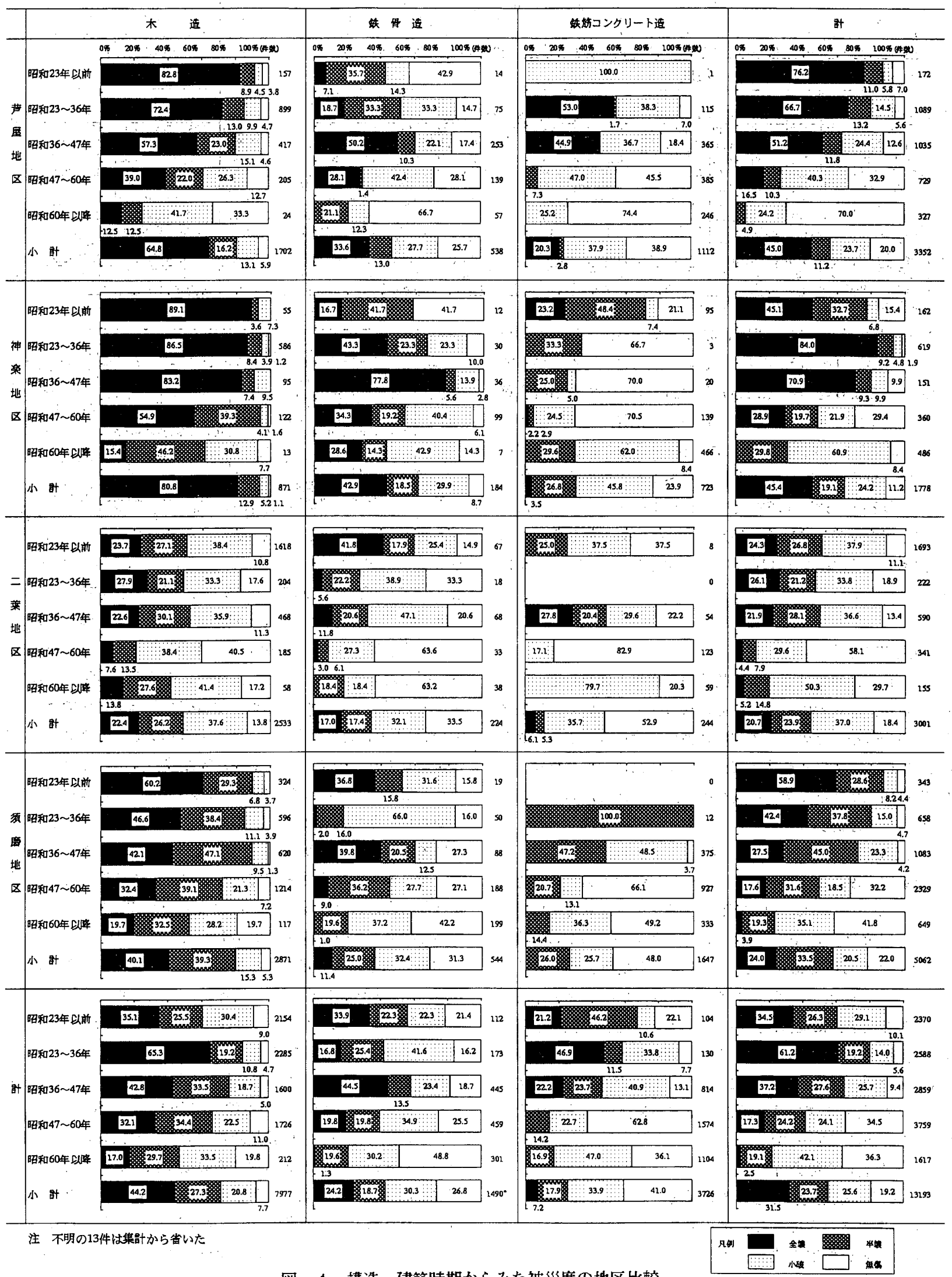

図一4 構造、建築時期からみた被災度の地区比較 


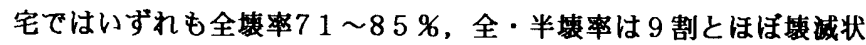

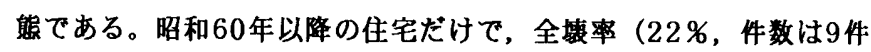
と少ないが）が小さい。芦屋地区でも古い文化・アパート，長屋は 一部半填があるが，ほぼ全壊状熊である。戸建住宅についても被害 が大きいが「昭和2 3 年以前」の全猿率8 2 \%という大きい被害か
ら，建築時期に比例して被害は域少している。

須磨地区は，上記 2 地区よりは被害は小さい。しかし昭和 47 年以 前の文化・アパート，長屋では，全壊で半数以上，全・半塤をあわ せると $90 \%$ と被害が大きい。戸建はそれよりは被害が少ないが, 被 害が小さくなるのは，やはり「昭和60年以降」（全埭率 $11 \%$ ）だけ

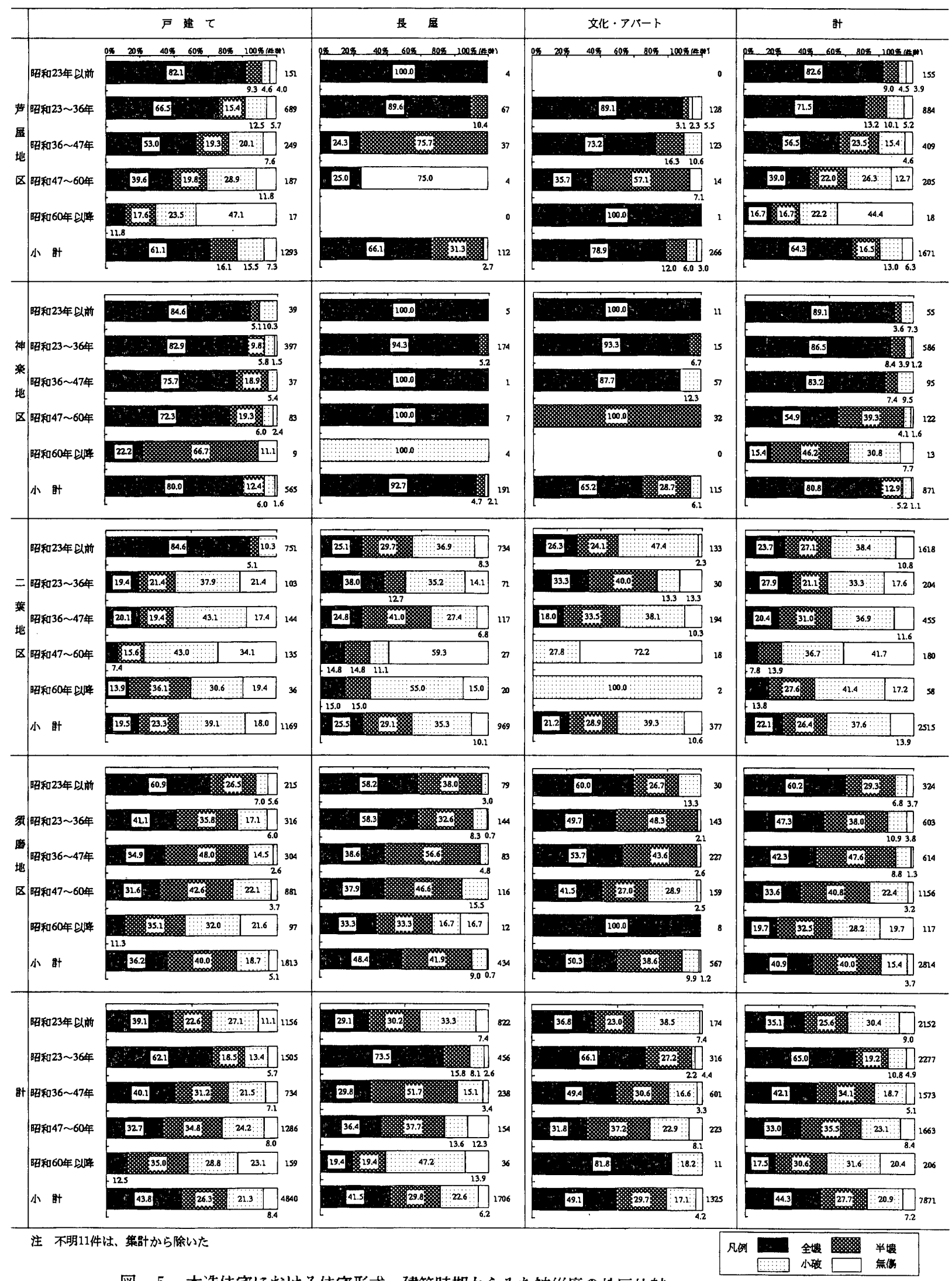

図一 5 木造住宅における住宅形式・建築時期からみた被炎度の地区比較 
である。二莱地区については, 被害が小さい。文化・アパート，長 屋で!昭和 23 年以前」の被害の方が相対的に小さい。その理由は, 二葉地区のなかでも最も被害の小さい南部の駒ケ林で屒屋や文化 アパートが多いからである。

以上, 住宅被害の実熊を, 構造, 住宅形式, 建築時期の閣係で分 析してきたが，各地区共通して「文化・アパート」の被害が大きい こと，芦屋より搂れが小さかったと思われる神楽地区での被害の大 きさを考えると，粗悪な材料の使用等，住宅の低質性も被害に影管 していると考えられる。

\section{3 住宅被害の要因䦥俰の考察}

最後に前節で分析してきた住宅構造別の被災度，と被害の大き かった木造住宅についての住宅形式別の被災度の地区比较について 被災要因関係の考察を行う。

考察のために，被災度と建築時期（老朽度）について次のように， 仮定する。被災度は全軽を 1.0 ，半塤を 0.5 ，小破を 0.1 ，無傷を 0 として建築時期ことに被災度の平均で表した(すべて全填なら1.0, 全く無傷なら0になる）。また建築時期（老朽度）については，建 䇣年数の経過を価值の㵋却割合としてとらえ，新築時を偩却 0 ，終 局時(築60年) を賃却1.0（100\%）とした いては，本研究では，ある幅を持った期間としているので，その中
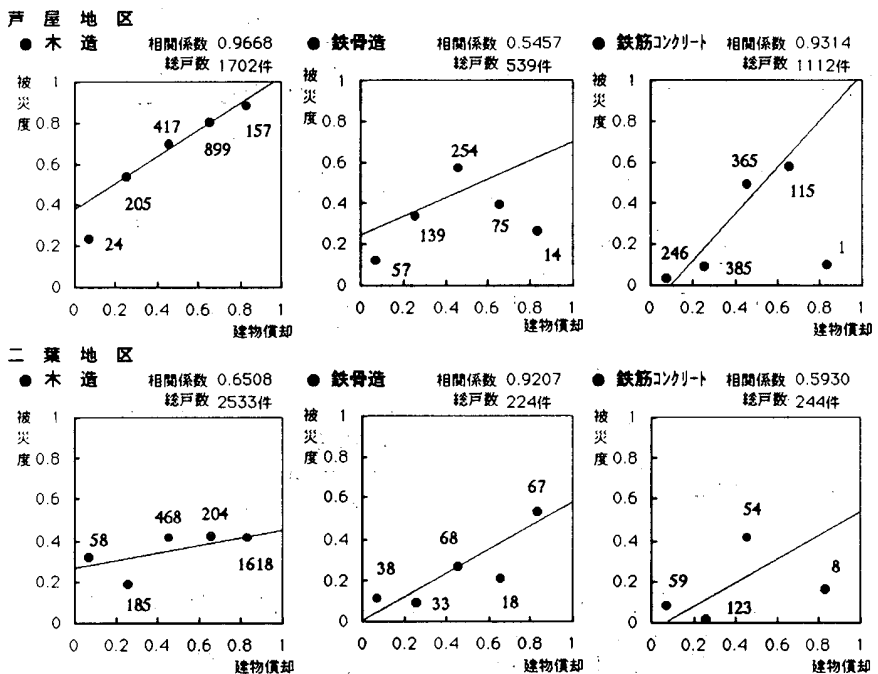

図一
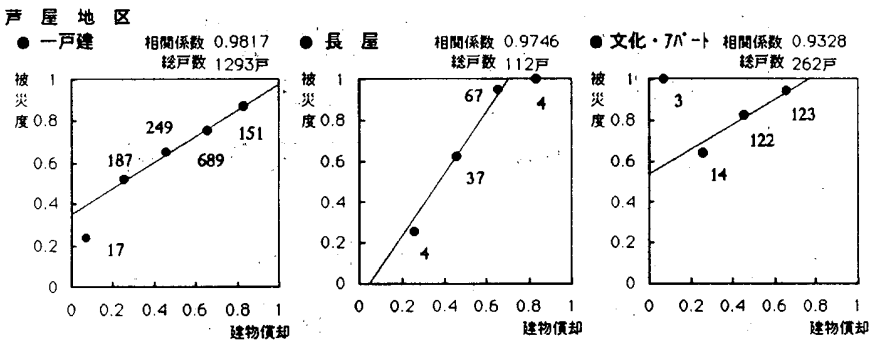

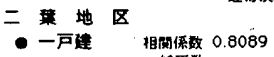
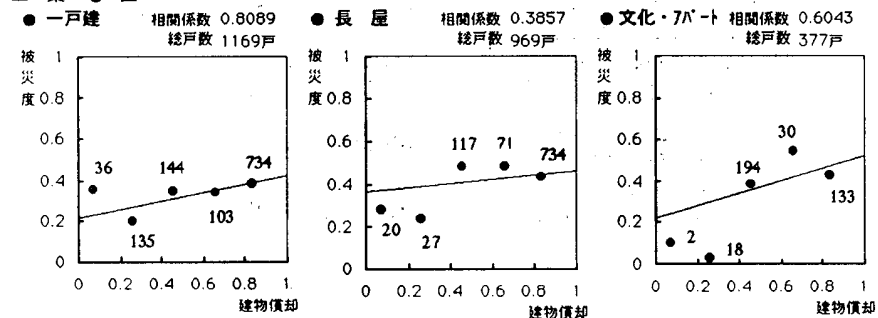

央值を建築年としたうえで，価值の偩却比率におきがた（昭和 60 年以降，47〜60年，36〜47年，23〜36年，23年以前，に建箱した ものが, 各々0.075, 0.258,0.458,0.658,0.833になる)。こ のように仮定すれば意味のある要因間の数量関係としてクララン表 すことができる。

図一 6 が地区別構造別にみた建築時期と被災度の関係を示したも のである。被害の大きい木造では, 神楽地区での昭和 47 年以前建築 の0.8〜0.9以上という罗滅に近い被害が目立つ。芦屋地区, 須磨地 区でも被害は大きく，建築時期と被害の相関は0.9 以上と高い。二 葉地区は，建筑時期にかかわらず被害が小さく，被炎度 0.5 以下の 被害である。鉄筋コンクリートの被害は最も小さいが，須磨地区を 除くと，建築時期と被害の関係はあまりみられない。鉄骨造も，被 害の小さい二葉地区を除くと建築時期との相関はみられない。しか し; 被害の大きい神楽地区, 芦屋地区では昭和 $36 \sim 47$. 年建築のも のに被害が大きいのが特街的である。

図一7 は地区別住宅形式別にみた木造住宅の建築時期と被災度の 関係を示したものである。前述した木造住宅と同様の傾向がみられ るがより明確である。神楽地区は長屋の被害ほぼ 1.0 をはじめ，新 しい建築時期のものを除くと壊隇である。芦屋地区では建築時期と 被害の関係が明膫で須磨も同じ傾向である。二葉地区は戸建て, 長
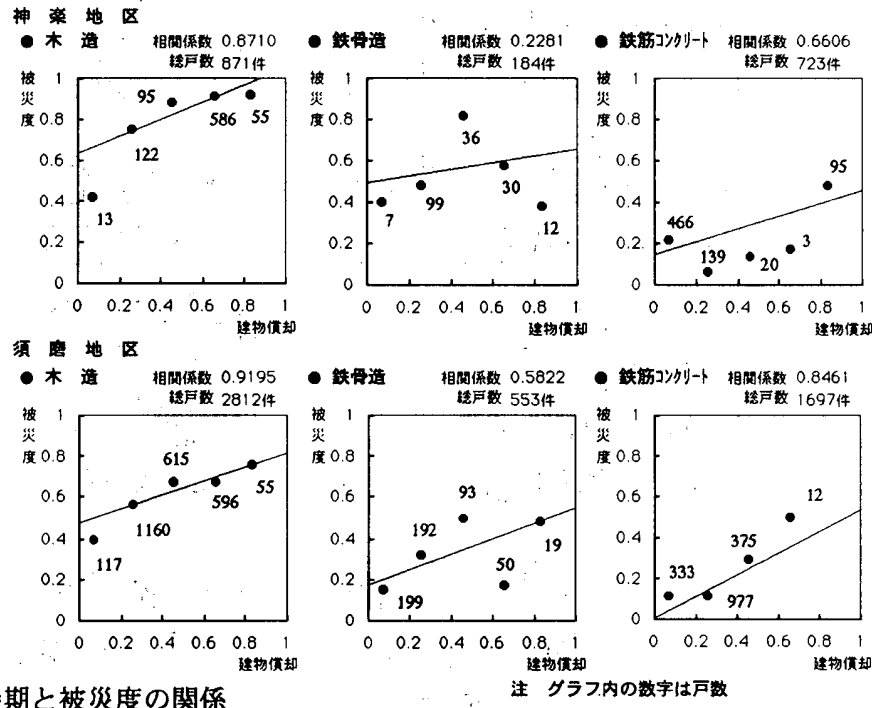

図一7 地区別住宅形式別にみた木造住宅の建築時期と被災度の関係

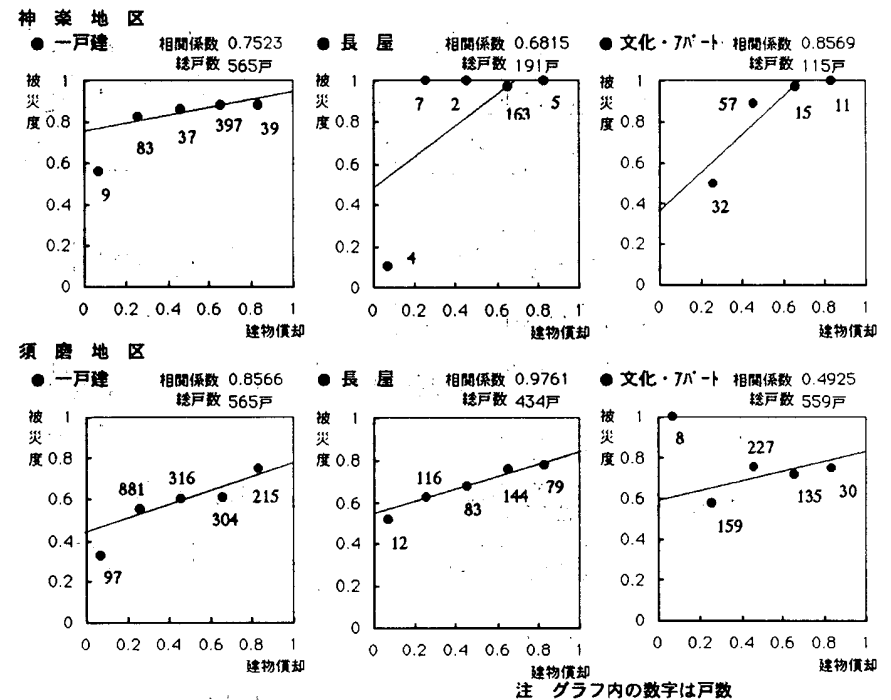


屋, 文化住宅・アパートとも被害は小さい。

\section{6. まとめ}

本論文の分析で明らかになった点をまとめると以下のように要的 できる。

（1）木造密集市街地は，構造（木造率），用途（混在率），住 宅形式，建築時期（老朽度）といった建物・住宅の状況および基盤 整借の状況によって槏々なタイプに分かれる。今回対象とした 4 地 区は，(1)芦屋地区（戸建住宅が主でマンションも立地，一部基盤未 整備），(2)神楽地区（ケミカルシューズを中心とした住工混在地 区，住宅は老朽長屋，街区内基篮未整備），(3)二葉地区（連担商店 街と老朽長屋からなる住商混在地区，街区内基盤未整備，被害は相 対的に小さい），(4)須磨地区（戸建住宅を主にマンション，艮屋， 文化・アパートも立地，地域のほとんどが基整末整借）といった特 徽をもつ。これら4 地区の震災前の市街地実態と震災被害の要因を 比較分析することは，大都市の木造密集市街地の今後のあり方に とって重要な知見を与えると考えられる。

（2）震災前の木造密集市街地はほほ２階建てであった。市街地 の性格は住宅特化から住商や住工の混在市街地まで多様であるが, いずれの地区とも非木造化が一定程度進行している。棟数でみれば 多くが戸建て住宅地であるが，戸数でみると集合住宅が混在する住 宅地へ変化している。

（3）地区別に市街地建物，住宅の被災度をみると，神楽，芦屋 地区の順で過半数が全坡し, 須磨地区でも全·半媴が70\%以上と被 害が大きい。それら被害の大きい 3 地区と比べると二葉地区では全 壊が 2 割程度で相対的に被害が少ない。前者の 3 地区は震度 7 地 域, 後者の 1 地区は震度 6 地域であり，当然震度の違いによる被害 の差は大きいが, 震度 7 地域といっても被害にかなりの差があるこ とが明らかになった。

（4）地区の主体となる住宅の被害をみると，構造では木造で当 然被害が大きく，鉄筋コンクリート造で小さい。しかし鉄骨造でも かなりの被害があり,鉄骨造では昭和 $36 \sim 47$ 年の建築時期のものに 被害が大きのが特徽である。また建筑時期と被害は相関しているが 木造では昭和 60 年までに建築された住宅での被害は大きく, 被害が 小さくなるのは昭和 60 年以降建策された新しい住宅だけである。

（5）住宅形式と被害の関係では，文化・アパートで最も被害が 大きく，ついで長屋，戸建の順である。しかし三者の差はあまりな くいずれも被害が大きい。それに比べ当然，非木造であるマンショ ンの被害は相対的に小さい。マンションでは，小規模なものの方が 被害が相対的に大きい。

（6）木造密集市街地の中心でありかつ被害の大きかった木造住 宅の被害を住宅形式，建築時期，地区との相関で分析すると重要な 被害実臆が明らかになる。被害の大きかった神楽地区では，文化・ アパート，長屋は，ほほ全诚状能である。戸建でも昭和 60 年建築よ り以前のものはほほほ全棲である。このことは東京，大阪のイン ナーシティに大量に存在する低質木儧住宅地域等に直下型地震が鼣 来した場合，震度のエリアでは大部分の住宅が全塤する恐れがある ことを示しているといえよう。

それに比べると，神楽地区の直ぐ近くに立地する二菓地区の住宅 で被害の少ないのは対照的であり，震度 6 であれば老朽長屋住宅や
文化・アパートといった今回大きな被害を受けた住宅タイプ等でも 全・半嘈にならない場合も多いことが明らかになった。

今後の課題としては，戸建て住宅での間口狭小住宅での被害の問 題や方位（地震の播れ方向）による被害の差があるのかといった点

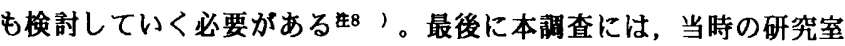
の院生，学生をはじめ，学年をこえたボランティアによる多くの協 カがあった。記して感謝したい。

\section{注 :}

注 1) 文化住宅・木造アパートは学街用語てはないが，関西では，一般的 に使用されているのでの用蓓を使用する。文化住宅は出入口，設備尃用の 2 室本賃住宅，木造アパートは出入口，設備共用の 1 室木賃住宅である。

注 2 ）本研究ては，4地区の市街地建物8,223侎，住宅13,792戸を対象に 一般化を図ることを意識したが，今回の直下型地震での被害は局地性も強 く，4地区各々のケーススタディになっていることも事実である。

注 3 ）震災後神戸市は，(1)土地区画整理事業や市街地再開発事業等の法定 都市計画事業区域（通称黒地区域），(2)住宅市街地総合整備事業や密集住宅 市街地整偏促進事業といった任意事業の重点復興地域（灰色地域），およひ 事実上の放置地域ともいえる震災復興促進区域（白地区域）に3区分した。

注 4）并用住宅は，戸建住宅（埸合によっては長屋）の中で店榬，工場等 と住宅に使用（一住戸の中で）している住宅をいう。并存住宅とは，集合住 宅（文化・アパート，マンション等）て，下階に店舗，工埸等が入る，いわ ゆるけたばき住梀になっているものをいう。長屋については，住戸単位では 併用住宅に，住棟単位で垪存住宅になる。

注 5）国土地理院が撮影している年度は，昭和 23 年，30 年，36 年，42 年，47年，53年，60年である。そのうち10 余年程度の時間間隔になるよう 考え、本論文て使用している 5 時点を選定した。

注6）なお别報として，被災による更地化の進行と建物，住宅の坂設・本 設による再建状況をトレースし，どのような市街地が形成されつつあるの か，居住者はどれだけ㞍っているのかを明らかにする研究を備している。

注 7 ）ミこ開発住宅とは， $1,000 \mathrm{~m}^{2}$ 末满の小規模な住宅地開発によって, 票地面稙 $100 \mathrm{~m}^{2}$ 未满の小見模戸建住宅が建設されることをいう。

注 8 ）本綸文の時期区分の昭和 23 年が築46年でり，昭和 23 年以前の住 宅がかなり存在したことから，終局時期を60 年とした。しかし，戦災時に多 くの被害を受けており，終局時期は50年の方加妥当かもしれない。

注 9 ）本諭文は，安藤元夫「木造密集市街地の実態と住宅被害の構造」 1996年度日本建筑学会大会（近畿）都市計画部門研究協議会資料に発表した ものをベースにしながら再集計，再分析を行ったものである。

参考文献：

1）阪神・路大度災住宅復興問題研究部会WG「住宅被災戸数調查 調査 の概要と住宅被害の特徽」都市住宅学，第14号，1996年6月。

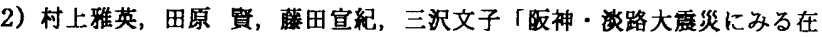
来不造都市型住宅の問題点」日本建策学会構造系諭文集, 第481号, pp71ミ 0,1996 年 3 月。

3）坂本 功監修 $\mathrm{r}$ 阪神大震災に見る木造住宅と地震』鹿島出版会，1997 年 4 月等。

4) 岸本幸臣「被災住宅戸数と再建必要戸数の再考」「大震災 3 年半・住宅

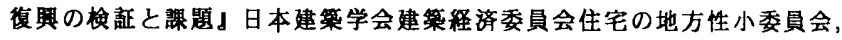
1998年 9 月。

5）三宅 醇「13 大都市における住宅被害の予則一神戸大震炎の型别被害 想定から一」「大度災 3 年半・住宅復興の检証之課題』日本建築学会建築程 済委員会住宅の地方性小委員会, 1998年 9 月。

(1998年6月10日原稿受理，1999年 1 月27日採用決定) 